\title{
THE PHENOMENON OF SLANG LANGUAGE ON FACEBOOK AND TWITTER
}

\author{
Istifatun Zaka
}

\begin{abstract}
This paper describes about the phenomenon of slang language on social network, namely facebook and twitter. Slang in this paper belongs to sociolinguistics study, especially sociolect. This is a descriptive qualitative method, which consists of three phase: data collection, data analysis, and presentation of the result of data analysis. The data were collected by observing the netters utterance. Data were analysed through two phases. First, analyzing the meaning of the slang. Second, was analysing the categories of the slang.

There are four point findings in this study. Firstly, the various forms of slang expression units are words and phrases. Secondly, the variety of linguistic processes forming units slang expression are by adding sound, erasing sound, changing vocal, replacing consonant, shifting sound, returning sound, repeating, and changing spell. Thirdly, the source languages of various slang reference units are from national language, regional languages, and foreign languages. Fourthly, the communicative functions of various units of slang expressions are informative function, directive function, expressive function, komisif function, phatic function, and poetic function. Finally, from the finding of those four points in this study, we know that slang language on facebook and twitter has its own uniqueness compared to other types of language.
\end{abstract}

Keyword: slang, facebook and twitter, forms of slang, linguistic processes, source languages, communicative functions.

\section{Introduction}

This study explains the phenomenon of slang language on facebook and twitter. It becomes interesting for some reasons. First, it is a variety of a language which is less prestigious and it will undermine the use of the standard language. Second, slang language appears frequently on facebook and twitter. Third, it has its own uniqueness compared to other types of language.

There are some previous studies on this field. They are Lestari (2005) who analyzed slang language on "kejayusan" site, Siswanto (2008) who examined slang language on friendster, and Setiawan (2010) who studied slang language on kaskus. Their studies have limited subject because they only focus on one object.

In this study, slang language belongs to sociolinguistics study, especially sociolect. This study is obtained one point that are the understanding of slang on facebook and twitter to find out the appropriate usage which depends on the situation and the condition. Then, this study will be decided into five parts those are the various forms of slang expression units, the variety of linguistic processes forming units slang expression, the souce languages of various slang reference units, and the communicative functions of various units of slang expressions. Finally, from this points finding in this study, we can know how the slang language has its own uniqueness compared to other types of language. 


\section{Various Forms of Slang Expression Units}

There are various forms of slang expression units by netters. They can be classified into two types, namely words and phrases. Words are a small component of language which has meaning. Slang words have two forms those are mono-morphemic and poly-morphemic. Verhaar (2008: 97) claimed that mono-morphemic is a word which consists of one or more morphemes, while polymorphemic is a word which consists of one morpheme. Slang phrases are all expression that consist of two or more words which are not predicative.

Base words various forms of slang expression units. Mono-morphemic words such as those in (1), (2), and (3). Poly-morphemic words constructed by morpheme and affixs such as those in (4), (5), and (6). Slang phrases such as those in (7 (8), and (9). All the slang expressions are showed below.
(1) bokap < 'father'
(2) ganjen < 'firtatious'
(3) kece < 'impressive'
(4) gebetan < 'friend date'
(5) FBan < 'plays or use facebook'
(6) PSan < 'plays playstation'
(7) brondong jagung < anak muda 'young people'
(8) duren super < duda keren suka perawan 'cool widower like a virgin'
(9) santi utomo < sampai nanti see you tomorrow 'see you later see you tomorrow'

\section{A Variety Of Linguistic Processes Forming Units Slang Expression}

Creating process of expression unit of slang language can be done in several ways. The processes of slang language lexicon are by adding sound, erasing sound, changing vocal, replacing consonant, shifting sound, returning sound, repeating, and changing spell.

The creating process of expression unit of slang language which is done by adding sound can be differentiated by adding consonant and affixs nge-. The adding consonant phonem can be distinguished based on two things those are adding consonant phonem in the front and in the middle of lexicon. The adding consonant in the next lexicon as seen in number (10) and (11). On the other side, the adding consonat in the middle of lexicon as seen in number (12) and (13) and the adding consonant in the end of lexicon as seen in number (14) dan (15). Then, the creating process of lexicon by adding affix $n g e$ - can be seen in number (15) and (16).
(10) ngomel < (ng+omel) 'grumble'
(11) ngemeng < (ng+emeng) 'talkative'
(12) gaswat < (ga (+s) wat) 'dangerous'
(13) jomblo < (jom $(+b)$ lo) 'singles'
(14) pertamaxx $<$ (pertama $+\mathrm{xx})$ ' first'
(15) $\operatorname{keduaxx}<$ (kedua $+\mathrm{xx}$ ) 'second'
(16) ngedate < (nge- + date) 'berkencan' 
(17) ngegombal < (nge- + gombal) 'prate'

The creating process of expression unit of slang language can also be done by erasing sound. This process is a general process because the pattern is simple and easy to be pronounced. It consists four types. The first is erasing sound in the front of word. It can be seen in the example below.

$$
\begin{aligned}
& \text { embem }<\text { tembem 'chubby' } \\
& \text { min }<\text { 'admin' } \\
& \text { gan }<\text { juragan 'boss' }
\end{aligned}
$$

The second is erasing sound in the end of word. It happens from foreign or Indonesian language. The words from foreign language which obtain the erasing sound in the end of word. It can be seen in the example number (21), (22), and (23). On the other hand, the erasing sound in the end of word of Indonesian language can be seen in number (24) to (26) as stated below:

(21) bro <'brother'

(22) narcis < 'narcisius'

(23) tajir < tajirun 'rich'

(24) sob < sobat 'friend'

(25) jau $<$ jauh 'far'

(26) dir < diri, direktur 'himself'

The third is erasing sound in the middle of word. It can be seen below.

(27) bert < berat 'heavy'

(28) wnet < warnet 'internet cafe'

The fourth is erasing disarrange sound. It happens in the initial, in the middle, and in the last word. The erasing sound in the initial and in the last word can be seen in the number (29). Then, the example of erasing sound in the middle and in the last word is in the number (30) and (31).

(29) yola < ayolah 'came on'

(30) ez < eazy 'easy'

(31) $\quad$ parno < paranoid 'afraid'

The next creating process of expression unit of slang language is changing vocal. The vocal is changed to produce expression unit to be more stylistic and intimate. In other word, it can be said as gaul. The changing of vocal has two types those are the changing from one vocal to other vocal, from one vocal to consonant, and diphthongization.

The changing vocal from one vocal to other vocal can be seen below.

(32) bogel < bugil 'bare'

(33) meneketehe < manakutahu 'i do not know'

(34) geblek < goblok 'bovine'

The changing vocal from one vocal to consonant can be found in the word creating process below. 


$$
\text { ajj < aja 'only' }
$$

The diphthongization process is a changing process of a phoneme becomes a diphthong. It can be seen in the example number (36), (37) and (38). As seen in those examples, the diphthongization process is followed by the erasing last phoneme.

(36) lebay < lebih 'over'

(37) lemay < lemah 'weak'

(38) $\quad$ sotoy $<$ sok tahu 'pretend to know'

The next creating process of expression unit of slang language can also be done by changing consonant. It relates to the pronunciation which imitates children, for example in the number (39). It can also be followed by erasing particular sounds, for example in the number (40).

(39) ckid < sakit 'sick'

(40) capcuz < cabut 'go away'

The creating process of expression unit of slang language can be done by interchanging sound. It is done by repositioning distribution of phonemes in one word. It is as seen below.

(41) cikil < licik 'sly'

(42) rebes < beres 'finished'

(43) yoi < iyo 'yes'

Besides those ways above, the creating process of expression unit of slang language can be done by exchanging the sound. It is different with repositioning sound because it is produced or spelled from last word so it can create new word. It can be seen below.

(44) $\quad$ kewut $<$ tuwek 'old'

(45) oges $<$ sego 'rice'

(46) ogeb < bego (bodoh) 'fatuous'

The next creating process of expression unit of slang language can be done by repetition. It can be done together with the erasing phoneme, like in the number (47) or it happens together between the erasing and the changing phoneme, then the repetition. The process can be seen in the number (48). This process is general because the creating of slang language always combines some processes together.

(47) $\operatorname{mimin}<$ 'admin'

(48) cengo-cengo < bengong-bengong 'dazed'

The creating process of expression unit of slang language can be done by briefing. There are four types of briefing. The first is briefing by compacting first phoneme in each component. It can be seen in the example number (49), (50), and (51).

IDL $<$ Itu Derita Loe 'Its Your Suffering'

GWS $<$ 'Get Well Soon' 
The second process is compacting first phoneme in each component with number. This process can be done if there is there is a repetition of word is first letter. It is as seen in the example number (52) and (53). Besides, it can be done by changing initial phoneme with number, the other phoneme is with phoneme. It is as seen in the example number (54) and (55). Furthermore, there is compacting first phoneme with phoneme or number, while the other compacting phoneme is done in the middle or last phoneme. This process as seen in the example number (56) and (57).

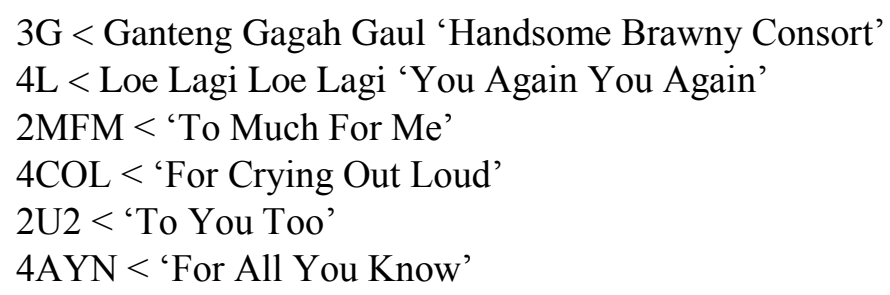

The third is briefing which can be done by compacting first phoneme in each component and it is followed by adding affixs. It can be seen in the example below:

$$
\begin{aligned}
& \text { BBan < BlackBerryan 'play blackberry' } \\
& \text { FBan < FaceBookan 'play facebook' } \\
& \text { kPDan < kepercayadirian 'selfreliant' }
\end{aligned}
$$

The fourth is the spelling phoneme from the briefing result. The creating process of expression unit of slang language is done by briefing first, then, the spelling phoneme which is resulted from briefing phenme. It can be seen below.

(61) Bete < BT ('Bad Tempered')

(62) Pede < PD (Percaya Diri) 'selfconfidencet'

The creating process of expression unit of other slang language is acronymic. It is a creating process of lexicon which is done by compacting component phonemes of creating lexicon or expression unit of slang language. This process is similar to briefing, but it happens in acronymic. The result of this process can be read similar to a word. In other word, acronymic is done by compacting some words into new words.

Acronymic as one of creating process of expression unit of slang language has eight types. The first is compacting one phoneme in each component. It is as seen in the example number (63) and (64). The second is compacting one phoneme of first component and three phoneme of second component. It can be seen in number (65) and (66). The third is compacting two phoneme in each component, for example in the number (67) and (68). The fourth is compacting two phoneme of first component and three phoneme of second component. It can be seen in the example number (69) and (70). The fifth is compacting three phoneme in each component, it can be seen in the number (71) and (72). The sixth is compacting three phoneme of first component and four phoneme of second 
component, it can be seen in the example number (73). The seventh is compacting four phoneme of first component and one phoneme of second component. It is as seen in the example number (74). The eighth is arbitrer compacting that is disarrange compacting to some phonemes and the position of phoneme in each component. It can be seen in the example number (75) to (77).

(63) $\quad$ lol < 'laugh out loud'

(64) ol < 'on line'

(65) alay < anak layangan, anak lebay 'kiteflyer, excessive children'

(66) imut $<$ item mutlak 'absolute black'

(67) lola < loading lama 'long loading'

(68) basuki < bajingan asu kirik 'crook dog pup'

(69) kuper $<$ kurang pergaulan 'less socially'

(70) bohai < body aduhai 'fantastic body'

(71) curhat $<$ curahan hati 'expression of feelings'

(72) kopdar < kopi darat 'meet cyberspace friend on real world'

(73) kultwit $<$ kuliah twitter 'college on twitter'

(74) selfi < self potrait'

(75) cilengsi < cinta lewat gengsi 'love through prestige'

(76) colenak < cowok jelek namun aksi 'ugly guy but action'

(77) ijo tomat $<$ ikatan jomblo terhormat 'bond respectable singles'

\section{Sources Languages of Various Slang Reference Units}

This section describes the sources of slang language on facebook and twitter. The discussion focuses on languages from which the slang expression are borrowed. There are so many languages to make it. So, in this section it will be divided into national language, regional language, and foreign languages.

The national language in Indonesia is Indonesian language. It is does not only have a standard variation, but also have a colloquial languages as well that is used by netters. Example number (78) to (80) bellow are form the Indonesian languages.

(78) $\quad$ cupu $<$ culun punya 'geeky'

(79) soked $<$ setan 'devil'

(80) $\quad$ sufi < suka film 'love movies'

Regional languages are used by various netters groups that inhabit the archipelago. Each netters group has its own languages. Several regional languages can be found in slang languages on facebook and twitter as shown in below. Example number (81) is from the Batak dialect. Betawi dialect can be found in (82). Sundanese word can be seen in (83). The last, the Javanese expression can be found in slang language as shown in example number (84).

(81) bodat $<$ monyet 'monkey'

(82) nyokap < ibu 'mother'

(83) bujur $<$ pantat 'ass'

(84) molor $<$ panjang 'long' 
Besides the national languages and regional languages, the foreign languages make a contribution to slang languages on facebook and twitter. English is the most influential foreign language that enriches the slang expression; consider number (85) and (86). Chinese words found in the number (87) and (88).

(85) SWL $<$ 'Screaming With Laughter'

(86) $\quad$ SPAM < 'Stupid Persons' Advertisement'

(87) konkow $<$ 'hang out'

(88) $\quad$ cici $<$ enci 'sister'

Several slang expression units combine one language with other. It can be seen below.

(89) lola < loading lama 'long loading'

(90) gembul < gemuk is beautiful 'big is beautiful'

(91) madona < manusia doyan nasi 'man hooked rice'

\section{The Communicative Functions of Various Units of Slang Expressions}

The slang language is used by netters to communicate their ideas. There are six communicative functions of various units of slang expressions. The first is informative function. The second is directive function. The third is expressive function. The fourth is komisif function. The fifth is phatic function. The sixth is poetic function.

The informative function relates to the function of language as the tool to express or to inform something. In this function, the focus of conversation is speaker. The directive function relates to aim of language to ask the hearer to do something. The expressive function relates to the function of language to express or to show the feelings. The phatic function relates to the function of language as the tool to build a relationship with the addressee. The poetic function relates to the purpose of language to express beauty.

The informative function is the general function of slang language. It is used by user to inform something to addressee. It can be seen in the example below.

(92) Dia itu marmin! > Dia itu makelar kelamin. 'He was a realtor sex'

(93) Emang dia itu kutilang darat. > Memang dia itu kurus, tinggi, langsing, dada rata. 'Indeed, she was skinny, tall, slim, flat chest.'

Slang language is similar to general language. It is used by user to ask the addressee to do something. It is as seen in the example below.

(94) Came on cabut, pren! > Ayo pergi, teman! 'Lets go, friend!'

(95) Jangan gitu player! > Jangan gitu plis dunk ah! 'Don’t be so, I implore!'

Slang language can be used to express feeling like happy, anger, sad, guilty, and others. For the detail, please look the example below.

(96) Syelen, emang siapa elo. > Sialan, emang siapa kamu. 'damn who you are'

(97) Asoi geboi, pewe banget euy gue di sini > Asik sekali, posisi enak ni di sini. 'Fun all, this good position here' 
Slang language is also used to make promise. It is as seen below.

(98) Sumpritt beneran bukan gue. > Sumpah betul bukan saya. Oath really not me.

(99) Nggak kemana-mana beneran deh, suweeerr kewer-kewer. > Sumpah saya tidak kemana-mana, sungguh. 'Oath I don't go anywhere, really.'

Slang language can be used to show the expression when we make a contact or end it. The example of it can be seen in the number (100) and (101).

(100) Misae > permisi 'excuse me'

(101) JK > Jumpa kembali 'See you back'

Slang language can be used by the user to create beautiful utterances. It can be seen in the example below.

(102) dedidores > dengan diiringi doa restu 'accompanied by blessing'

(103) djarum > demi jandamu aku rela untuk mati 'for the sake of your widow I am willing to die'

\section{Conclusion}

There are four point findings in this study. Firstly, the various forms of slang expression units are words and phrases. Slang words have two forms, namely mono-morphemic and poly-morphemic. Secondly, the variety of linguistic processes forming units slang expression are by adding sound, erasing sound, changing vocal, replacing consonant, shifting sound, returning sound, repeating, and changing spell. Thirdly, the source languages of various slang reference units are from national language, regional languages, and foreign languages. Regional languages are used are Batak, Betawi, Sundanese, and Javanese languages. The foreign languages consist of English and Chinese. Fourthly, the communicative functions of various units of slang expressions are informative function, directive function, expressive function, comisive function, phatic function, and poetic function. Finally, from this point findings in this study, we know that slang language on facebook and twitter has its own uniqueness compared to other types of language.

\section{REFERENCES}

Agung, W. 2009. 7 Hari Jago Facebook. Yogyakarta: Garailmu.

Arifin, Z. \& Junaiyah. 2009. Morfologi: Bentuk, Makna, dan Fungsi. Edisi Kedua. Cetakan Ketiga. Jakarta: Grasindo.

Holmes, Janet. 1995. An Introduction to Sociolinguistics. New York: Longman.

Kridalaksana, H. 2009. Pembentukan Kata dalam Bahasa Indonesia. Cetakan Kelima. Jakarta: PT Gramedia Pustaka Utama.

Lestari, Felicitas Wiji. 2005. Pemakaian Slang di antara Kaum Jayus dalam Situs-situs Kejayusan di Internet (Sebuah Studi Kasus). Tesis. Fakultas Ilmu Budaya Universitas Gadjah Mada. 
Moleong, L. J. 2009. Metodologi Penelitian Kualitatif. Edisi Revisi. Cetakan Keduapuluhenam. Bandung: PT Remaja Rosdakarya.

Setiawan, Budi. 2010. Slang Komunitas Kaskus di Internet, Suatu Kajian Sosiolinguistik. Tesis. Fakultas Ilmu Budaya Universitas Gadjah Mada.

Siswanto, Adrian. 2008. Ragam Bahasa Profil Pengguna Friendster (FS) di Internet. Skripsi. Fakultas Ilmu Budaya Universitas Gadjah Mada.

Verhaar, J.W.M. 2008. Asas-asas Linguistik Umum. Cetakan Kelima. Yogyakarta: Gadjah Mada University Press.

Wardhaugh, R. 1988. An Introduction to Sociolinguistics. New York: Basil Blackwell.

Wijana, I Dewa Putu. 2011. The Development of Bahasa Indonesia in Multicultural Context: A Case Study of Adoloscent's Slang. On Humaniora Journal, Volume 23 no 1 February 2011. Page 7178.

Name

: Istifatun Zaka

Address : Kajar RT03 RW36, Sidomulyo, Bambanglipuro, Bantul, DIY 55764

Phone Number (HP) : 085643559998

Email : zakaistifa@gmail.com

Affiliation : Gadjah Mada University (alumni) 